\title{
Pemodelan Dan Analisis Pengaruh Variasi Oli dan Diameter Orifice terhadap Gaya Redam Shock Absorber Dan Respon Dinamis Sepeda Motor Yamaha Jupiter Z 2008
}

\author{
Newanda Asa Wahid dan Wiwiek Hendrowati \\ Teknik Mesin, Fakultas Teknologi Industri, Institut Teknologi Sepuluh Nopember (ITS) \\ Jl. Arief Rahman Hakim, Surabaya 60111 Indonesia \\ e-mail:wiwiek@me.its.ac.id
}

\begin{abstract}
Abstrak-Sepeda motor merupakan moda transportasi yang paling banyak diminati oleh masyarakat Indonesia. Dalam hal kenyamanan, maka komponen sepeda motor yang berperan penting adalah sistem suspensi. Sistem suspensi berfungsi menyerap getaran berlebih akibat profil permukaan jalan, sehingga meningkatkan kenyamanan dan keamanan. Oleh karena itu, perlu dilakukan penelitian untuk mendapatkan sistem suspensi yang terbaik. Dalam tugas akhir ini dilakukan pemodelan dan analisis pengaruh perubahan parameter sistem suspensi sepeda motor Yamaha Jupiter Z 2008 khususnya pada komponen monotube hydraulic shock absorber yang didasarkan pada pemodelan setengah kendaraan. Parameter yang divariasikan adalah tipe oli dan diameter orifice, dimana terdapat 5 macam tipe oli dengan rentang nilai massa jenis ( $\rho$ ) sebesar $845-874 \mathrm{~kg} / \mathrm{m}^{3}$, dan viskositas (v) sebesar 11,3 - 46 $\mathrm{mm}^{2} / \mathrm{s}$, sementara untuk diameter orifice yaitu saat kompresi (Docomp) sebesar 1,2 - 1,5 mm, saat ekspansi (Doxp) sebesar 0,8 - $1 \mathrm{~mm}$. Input yang digunakan pada simulasi adalah input sinusoidal dan input bump modified. Dari penelitian ini didapatkan hasil bahwa sistem suspensi modifikasi monotube hydraulic shock absorber yang menghasilkan gaya redam optimal memiliki nilai parameter viskositas kinematis oli 46 $\mathrm{mm}^{2} / \mathrm{s}$, massa jenis oli $845 \mathrm{~kg} / \mathrm{m}^{3}$, diameter orifice kompresi $0,00135 \mathrm{~m}$, dan diameter orifice ekspansi $0,0009 \mathrm{~m}$. Nilai gaya redam optimal yang dihasilkan sistem suspensi modifikasi adalah sebesar 1171,3 $\mathrm{N}$, lebih tinggi hingga 546,44 $\mathrm{N}$ dibandingkan dengan gaya redam sistem supensi asli yang bernilai 624,86 N pada frekuensi $2 \mathrm{~Hz}$. Pada sistem setengah kendaraan motor dengan penggunaan sistem suspensi asli maupun modifikasi, untuk input bump, respon kendaraan dan penumpang mencapai steady state kurang dari 2 detik dan 5 detik, sedangkan untuk input sinusoidal responnya mencapai steady state kurang dari 2 detik dan 3 detik. Penggunaan suspensi asli maupun modifikasi menghasilkan nilai perpindahan RMS yang meningkat mulai kecepatan $10 \mathrm{~km} / \mathrm{jam}$ hingga 20 km/jam, kemudian mulai menurun saat kecepatan 40 km/jam hingga $80 \mathrm{~km} / \mathrm{jam}$. Apabila ditinjau dengan standar ISO 2631, penggunaan suspensi modifikasi menghasilkan kenyamanan yang sedikit lebih baik dibanding dengan suspensi asli pada semua kecepatan.
\end{abstract}

Kata Kunci-monotube hydraulic shock absorber, viskositas, massa jenis, orifice, gaya redam.

\section{PENDAHULUAN}

$\mathrm{B}$ ERDASARKAN data Badan Pusat Statistik, jumlah sepeda motor yang beroperasi di Indonesia semakin meningkat, tercatat pada tahun 2013 jumlahnya telah mencapai 84.732.652 unit sepeda motor. Hal ini menunjukkan tingginya minat masyarakat terhadap sepeda motor, sehingga produsen-produsen bersaing memproduksi sepeda motor yang irit, ramah lingkungan, dan tentunya nyaman. Dalam hal kenyamanan, maka faktor utama yang berperan adalah sistem suspensi.

Sistem suspensi motor merupakan bagian penting pada chasis sepeda motor yang berfungsi menyerap getaran berlebih akibat permukaan jalan. Jenis sistem suspensi yang banyak digunakan di Indonesia khususnya pada body sepeda motor bagian belakang adalah suspensi monotube hydraulic shock absorber. Untuk meningkatkan keamanan dan kenyamanan berkendara maka telah ditetapkan standar internasional mengenai getaran pada kendaraan yang harus dipenuhi, yaitu ISO 2631/1974 ${ }^{[3]}$, sehingga sistem suspensi harus memiliki nilai kekakuan dan redaman yang sesuai.

Perubahan parameter yang dilakukan khususnya pada komponen peredam hidrolik seperti massa jenis oli, viskositas oli dan diameter orifice akan mempengaruhi karakteristik redaman dari sistem suspensi tersebut, serta dapat mempengaruhi respon dinamis dari sepeda motor saat sistem suspensi tersebut dipasangkan pada motor. Oleh karena itu, dalam tugas akhir ini dilakukan perancangan ulang dan analisis sistem suspensi sepeda motor Yamaha Jupiter Z 2008 yang didasarkan pada pemodelan setengah kendaraan untuk memperoleh desain yang lebih baik.

\section{URAIAN PENELITIAN}

Sistem suspensi monotube hydraulic shock absorber yang terdapat pada sepeda motor Yamaha Jupiter Z ini, memiliki parameter yang mempengaruhi gaya redamannya, yaitu diameter orifice kompresi dan ekspansi, nilai densitas dan viskositas oli, serta luasan pada sisi kompresi dan sisi ekspansi. Parameter-parameter tersebut kemudian divariasikan, kemudian diperoleh parameter optimal dan diaplikasikan pada setengah kendaraan sepeda motor.

Simulasi dilakukan pada dua sistem, yaitu system suspensi monotube hydraulic shock absorber dengan penggunaan parameter asli dan dimodifikasi, dan sistem setengah kendaraan. Kedua sistem tersebut ditunjukkan pada gambar 1 dan 2. Pada saat eksekusi simulasi, digunakan dua macam input, yaitu pertama, input sinusoidal yang akan menghasilkan respon steady-state pada pengetesan sistem suspensi monotube hydraulic shock absorber. Kedua, input bump yang dimodifikasi yang akan menghasilkan respon transien pada sistem suspensi monotube hydraulic shock absorber. 


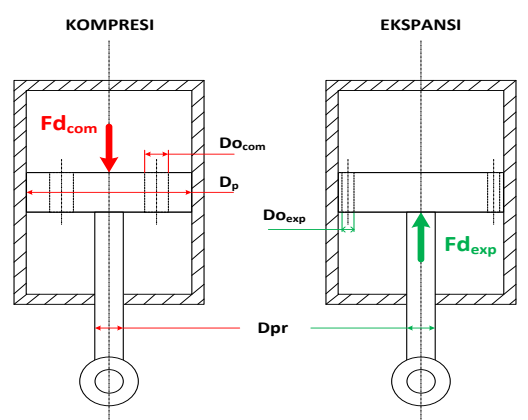

Gambar. 1. Sistem Suspensi Monotube Hydraulic Shock Absorber

Berdasarkan pemodelan suspensi seperti gambar 1 diatas, dan ditinjau melalui persamaan kesetimbangan energi kinetik dengan head loss, maka diperoleh persamaan gaya redam suspensinya sebagai berikut:

Sistem Suspensi monotube hydraulic shock absorber

- Gaya Redam Siklus Kompresi

$$
\begin{gathered}
F d=\Delta P \cdot A_{p}=\left[\frac{1}{2}\left(\left(\frac{A_{p}}{A_{o}}\right)^{2}-1\right) \dot{x}_{s}{ }^{2}+h_{l T}\right] \cdot \rho \cdot A_{\mathrm{p}} \\
F d_{\text {kom }}=\left[\frac{1}{2}\left(\left(\frac{A_{p}}{A_{o 1}}\right)^{2}-1\right) \dot{x}_{s}{ }^{2}+\frac{32 L v}{D_{o 1}{ }^{2}} \dot{x}_{o 1}+\right. \\
\left.K \frac{\dot{x}_{o 1}{ }^{2}}{2}\right] \rho \cdot A_{p}
\end{gathered}
$$

- Gaya Redam Siklus Ekspansi

$$
\begin{gathered}
F d=\Delta P \cdot A_{p}=\left[\frac{1}{2}\left(\left(\frac{A_{p}}{A_{o}}\right)^{2}-1\right) \dot{x}_{s}{ }^{2}+h_{l T}\right] \cdot \rho \cdot A_{\mathrm{p}} \\
F d_{e k s}=\left[\frac{1}{2}\left(\left(\frac{A_{p}-A_{p r}}{A_{O 2}}\right)^{2}-1\right) \dot{x}_{s}{ }^{2}+\frac{32 L v}{D_{o 2}{ }^{2}} \dot{x}_{o 2}+\right. \\
\left.K \frac{\dot{x}_{o 2}{ }^{2}}{2}\right] \rho \cdot\left(A_{p}-A_{p r}\right)
\end{gathered}
$$

Berikut adalah gambar 2 mengenai pemodelan sistem setengah kendaraan sepeda motor:
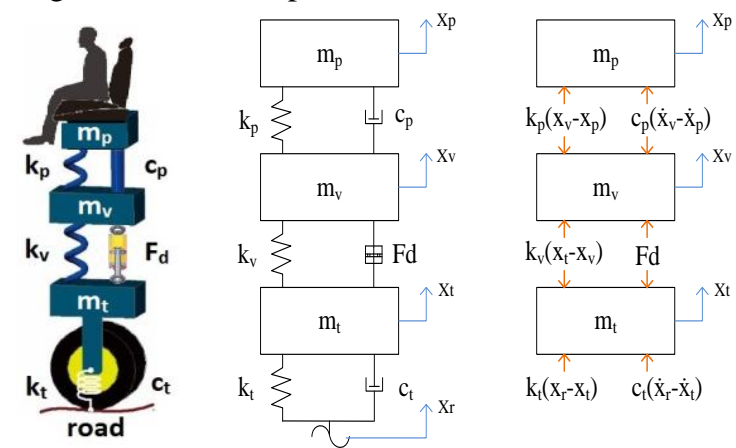

$\mathrm{k}_{\mathrm{v}}\left(\mathrm{x}_{\mathrm{t}}-\mathrm{x}_{\mathrm{v}}\right) \quad \mathrm{Fd}$

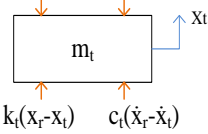

Gambar. 2. Sistem Setengah Kendaraan Sepeda Motor Bagian Belakang

Berdasarkan pemodelan pada gambar 2 diperoleh persamaan dan state variable sebagai berikut:

Sistem Setengah Kendaraan pada Sistem Suspensi Hydraulic Shock Absorber

- Persamaan gerak untuk massa ban $\left(\mathrm{m}_{\mathrm{t}}\right)$ dapat dijabarkan sebagai berikut:

$\sum F_{y}=m_{t} \ddot{x}_{t}$

$k_{t}\left(x_{r}-x_{t}\right)+c_{t}\left(\dot{x}_{r}-\dot{x}_{t}\right)-k_{v}\left(x_{t}-x_{v}\right)-F_{D}=$

$m_{t} \ddot{x}_{t}$

$\dot{v}_{t}=\frac{1}{m_{t}}\left[k_{t}\left(x_{r}-x_{t}\right)+c_{t}\left(\dot{x}_{r}-\dot{x}_{t}\right)-k_{v}\left(x_{t}-\right.\right.$

$\left.\left.x_{v}\right)-F_{D}\right]$
- $\quad$ Persamaan gerak untuk massa kendaraan $\left(\mathrm{m}_{\mathrm{v}}\right)$ dapat dijabarkan sebagai berikut:

$\sum F_{y}=m_{v} \ddot{x}_{v}$

$k_{v}\left(x_{t}-x_{v}\right)+F_{d}-k_{p}\left(x_{v}-x_{p}\right)-c_{p}\left(\dot{x}_{v}-\dot{x}_{p}\right)=$ $m_{v} \ddot{x}_{v}$

$\dot{v}_{v}=\frac{1}{m_{v}}\left[k_{v}\left(x_{t}-x_{v}\right)+F_{d}-k_{p}\left(x_{v}-x_{p}\right)-\right.$

$\left.c_{p}\left(\dot{x}_{v}-\dot{x}_{p}\right)\right]$

- $\quad$ Persamaan gerak untuk massa penumpang $\left(\mathrm{m}_{\mathrm{p}}\right)$ dapat dijabarkan sebagai berikut:

$$
\begin{aligned}
& \sum F_{y}=m_{p} \ddot{x}_{p} \\
& k_{p}\left(x_{v}-x_{p}\right)+c_{p}\left(\dot{x}_{v}-\dot{x}_{p}\right)=m_{p} \ddot{x}_{p} \\
& \dot{v}_{p}=\frac{1}{m_{p}}\left[k_{p}\left(x_{v}-x_{p}\right)+c_{p}\left(\dot{x}_{v}-\dot{x}_{p}\right)\right]
\end{aligned}
$$

\begin{tabular}{|c|c|c|c|}
\hline \multicolumn{4}{|c|}{ Parameter Variasi Jenis Oli } \\
\hline No. & Brand & Parameter & Nilai \\
\hline \multirow[b]{2}{*}{1.} & \multirow[b]{2}{*}{$\begin{array}{l}\text { Motul Shock } \\
\text { Oil }(2,5-20)\end{array}$} & Massa jenis $\left(\rho_{1}\right)$ & $\mathrm{kg} / \mathrm{m}^{3}$ \\
\hline & & $\begin{array}{l}\text { Viskositas } \\
\text { kinematis }\left(v_{1}\right)\end{array}$ & $16,10 \mathrm{~mm}^{2} / \mathrm{s}$ \\
\hline \multirow[b]{2}{*}{2.} & \multirow[b]{2}{*}{$\begin{array}{l}\text { Agip Fork } \\
(5 w t)\end{array}$} & Massa jenis $\left(\rho_{3}\right)$ & $\mathrm{kg} / \mathrm{m}^{3}$ \\
\hline & & $\begin{array}{l}\text { Viskositas } \\
\text { kinematis }\left(v_{3}\right)\end{array}$ & $22,00 \mathrm{~mm}^{2} / \mathrm{s}$ \\
\hline \multirow[b]{2}{*}{3.} & \multirow{2}{*}{$\begin{array}{l}\text { Maxima } \\
(10 w t)\end{array}$} & Massa jenis $\left(\rho_{3}\right)$ & $\mathrm{kg} / \mathrm{m}^{3}$ \\
\hline & & $\begin{array}{l}\text { Viskositas } \\
\text { kinematis }\left(v_{3}\right)\end{array}$ & $32,00 \mathrm{~mm}^{2} / \mathrm{s}$ \\
\hline \multirow[b]{2}{*}{4.} & \multirow{2}{*}{$\begin{array}{l}\text { Repsol Moto } \\
\text { Fork Oil } \\
(10 w t)\end{array}$} & Massa jenis $\left(\rho_{4}\right)$ & $\mathrm{kg} / \mathrm{m}^{3}$ \\
\hline & & $\begin{array}{l}\text { Viskositas } \\
\text { kinematis }\left(v_{4}\right)\end{array}$ & $46,00 \mathrm{~mm}^{2} / \mathrm{s}$ \\
\hline
\end{tabular}

Parameter-parameter untuk pemodelan pada gambar 1 dan 2 diperoleh dari jurnal dan dari pengujian secara langsung.

Tabel 1.

Parameter sistem suspensi asli hydraulic shock absorber

\begin{tabular}{ll}
\hline Parameter & Nilai \\
\hline Koefisien discharge orifice $(\xi)$ & 0,3 \\
Diameter piston $\left(\mathrm{D}_{\mathrm{p}}\right)$ & $0,016 \mathrm{~m}$ \\
Diameter piston rod $(\mathrm{Dpr})$ & $0,008 \mathrm{~m}$ \\
Diameter orifice kompresi $\left(\mathrm{Do}_{\mathrm{com} 1}\right)$ & $0,0015 \mathrm{~m}$ \\
Diameter orifice ekspansi $\left(\mathrm{Do}_{\mathrm{exp} 1}\right)$ & $0,001 \mathrm{~m}$ \\
Massa jenis oli shock absorber awal $\left(\rho_{0}\right)$ & $859 \mathrm{Kg} / \mathrm{m}^{3}$ \\
Viskositas kinematis oli $\left(v_{0}\right)$ & $11,30 \mathrm{~mm}^{2} / \mathrm{s}$ \\
\hline
\end{tabular}

Tabel 2.

Parameter Variasi Jenis Oli

Dalam pemodelan ini didapatkan respon dinamis dari sistem suspensi monotube hydraulic shock absorber dan sistem setengah kendaraan motor dengan penggunaan sistem suspensi monotube hydraulic shock absorber dengan parameter asli dan parameter modifikasi. Respon dinamis pada sistem suspensi monotube hydraulic yang dibahas pada bab ini adalah respon perpindahan dan kecepatan terhadap gaya redam. Pada grafik respon gaya redam yang dihasilkan, nilai positif adalah nilai pada kondisi kerja kompresi, dan nilai negatif adalah nilai pada kondisi kerja ekspansi. Pada sistem setengah kendaraan, respon dinamis yang dibahas adalah respon perpindahan, kecepatan, dan percepatan getaran yang dialami oleh penumpang terhadap perubahan waktu.

Simulasi pertama yang dilakukan adalah simulasi dari sistem suspensi monotube hydraulic shock absorber, diawali dengan penggunaan parameter asli yang akan digunakan sebagai acuan atau pembanding. Hal pertama yang dilakukan 
dalam simulasi adalah pemilihan variasi jenis oli, yang mencakup variasi viskositas dan massa jenis, dimana variasi viskositas oli 11,3 - 46 cSt, dan variasi massa jenis oli 845 $874 \mathrm{~kg} / \mathrm{m}^{3}$. Kemudian dari setiap variasi jenis oli akan divariasikan diameter orifice-nya, dimana diameter orifice kompresi $0,0015 \mathrm{~m} ; 0,00135 \mathrm{~m} ; 0,0012 \mathrm{~m}$, dan diameter orifice ekspansi $0,001 \mathrm{~m} ; 0,0009 \mathrm{~m} ; 0,0008 \mathrm{~m}$. Input yang digunakan yaitu input sinusoidal, dimana variasi frekuensinya $0.5-2 \mathrm{~Hz}$. Untuk nilai amplitudo ditentukan konstan sebesar $2 \mathrm{~cm}$. Dari simulasi ini akan didapatkan nilai gaya redam sistem suspensi dengan parameter asli dan modifikasi. Dari hasil simulasi tersebut kemudian dibandingkan untuk memperoleh variasi parameter modifikasi yang menghasilkan gaya redam yang optimal, dimana selanjutnya akan digunakan pada simulasi sistem setengah kendaraan sepeda motor.

Sistem suspensi monotube hydraulic shock absorber yang optimal kemudian diaplikasikan pada sistem setengah kendaraan motor dengan input yang digunakan, yaitu input sinusoidal yang mewakili variasi kecepatan motor, dan input bump yang dimodifikasi dengan severity parameter $(\gamma)$ bernilai $1 ; 5 ; 20$ yang mewakili variasi beban impact. Dari kedua input ini didapatkan respon dinamis dari penumpang maupun sepeda motor. Kemudian respon dinamis tersebut dibandingkan dengan standar ISO 2631 untuk mengetahui kriteria kenyamanan dan ketahanan penumpang berdasarkan nilai percepaan RMS.

\section{HASIL DAN ANALISA}

Dalam pemodelan ini didapatkan respon dinamis dari sistem suspensi hydraulic shock absorber saat penggunaan sistem suspensi asli dan sistem suspensi modifikasi.

3.1 Respon Dinamis Sistem Suspensi Monotube Hydraulic Shock Absorber Dengan Variasi Diameter Orifice, Viskositas Oli, dan Massa Jenis Oli

Dalam pemilihan gaya redam optimal, maka terdapat kriteria-kriteria yang harus dipenuhi, yaitu:

1) Nilai gaya redam yang besar

Nilai gaya redam yang besar akan cenderung menghasilkan respon yang lebih rendah, terutama pada kecepatan tinggi, namun harus tetap diperhatikan agar rasio redamannya $0<\xi<1$ (underdamp).

2) Karakteristik redaman yang dihasilkan

Perlu dilihat karakteristik redamannya berdasarkan rasio redaman yang dihasilkan, hal ini bertujuan agar terhindar dari redaman yang overdamp dan critical damp.

3) Kenyamanan yang dihasilkan

Semakin kecil nilai percepatan RMS yang dihasilkan, maka kenyamanan semakin baik.

Berikut ini merupakan grafik yang dihasilkan dari simulasi untuk pengetesan sistem suspensi hydraulic shock absorber saat penggunaan system suspensi asli dengan input sinusoidal. Gambar 3 merupakan grafik respon gaya redam terhadap perpindahan dan kecepatan dengan variasi frekuensi $0.5 \mathrm{~Hz} ; 1 \mathrm{~Hz} ; 1.5 \mathrm{~Hz} ; 2 \mathrm{~Hz}$.
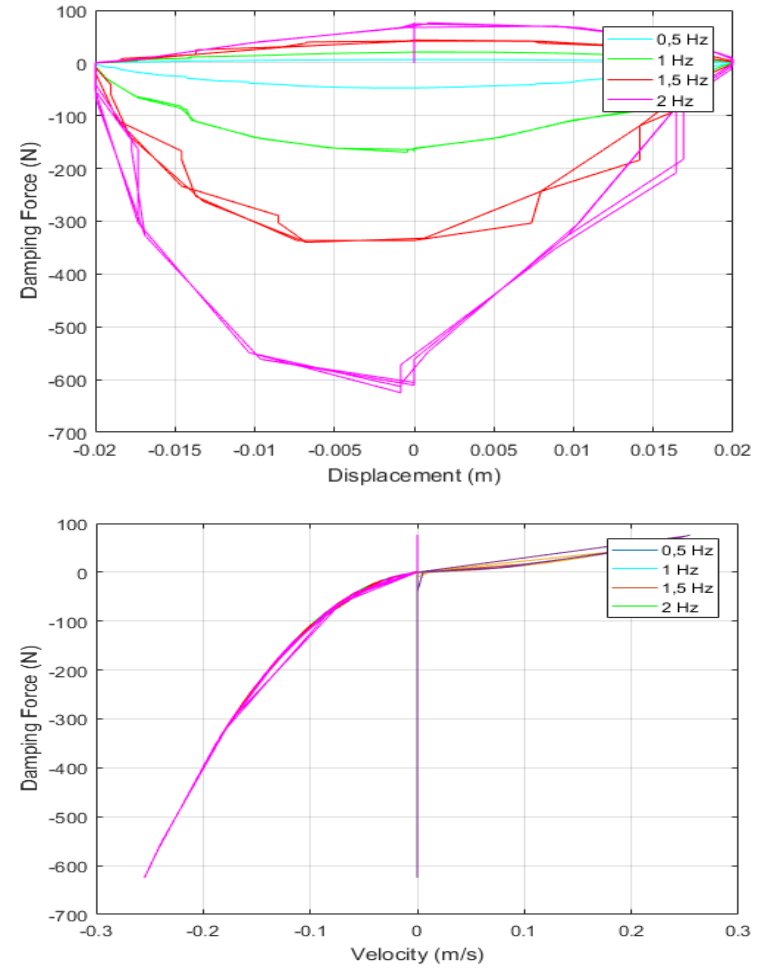

Gambar 3.Grafik respon gaya redam suspensi asli terhadap perpindahan dan kecepatan dengan variasi frekuensi $0.5 \mathrm{~Hz} ; 1 \mathrm{~Hz} ; 1.5 \mathrm{~Hz} ; 2 \mathrm{~Hz}$.

Pada grafik respon gaya redam terhadap perpindahan terlihat jelas bahwa semakin besar frekuensi, maka gaya redam yang dihasilkan semakin besar. Perlu diketahui bahwa respon gaya redam parameter asli juga diperoleh melalui simulasi MATLAB dengan menggunakan rumus gaya redam (Fd) persamaan 1 dan 2, sehingga hasil dari suspensi asli maupun modifikasi membentuk grafik yang relatif sama, namun dengan nilai yang berbeda.

Berikut ini adalah detail hasil simulasi gaya redam:

Tabel 3.

\begin{tabular}{|c|c|c|c|c|}
\hline \multicolumn{5}{|c|}{ Detail hasil simulasi gaya redam } \\
\hline \multirow[t]{2}{*}{$\begin{array}{c}\text { JENIS } \\
\text { OLI }\end{array}$} & $\begin{array}{c}\text { Fd } \\
\text { kompresi } \\
(\mathrm{N})\end{array}$ & $\begin{array}{c}\mathrm{Fd} \\
\text { ekspansi } \\
(\mathrm{N})\end{array}$ & $\xi$ & \multirow[t]{2}{*}{ Ket. } \\
\hline & $2 \mathrm{~Hz}$ & $2 \mathrm{~Hz}$ & $\mathrm{C} / \mathrm{Cc}$ & \\
\hline \multirow{3}{*}{$\begin{array}{l}\text { Yamaha } \\
\text { (KYB) }\end{array}$} & 76,24 & 624,86 & 0.494096 & underdamp \\
\hline & 116,21 & 952,40 & 0.736275 & underdamp \\
\hline & 186,15 & 1525,6 & 1.17775 & overdamp \\
\hline \multirow{3}{*}{ Motul } & 81,44 & 657,78 & 0.509426 & underdamp \\
\hline & 124,13 & 1002,6 & 0.776466 & underdamp \\
\hline & 198,85 & 1605,9 & 1.244044 & overdamp \\
\hline \multirow{3}{*}{$\begin{array}{l}\text { Agip } \\
5 w t\end{array}$} & 84,52 & 671,51 & 0.521028 & underdamp \\
\hline & 128,82 & 1023,5 & 0.794282 & underdamp \\
\hline & 206,36 & 1639,5 & 1.272426 & overdamp \\
\hline \multirow{3}{*}{$\begin{array}{l}\text { Maxima } \\
10 \mathrm{wt}\end{array}$} & 93,71 & 726,49 & 0.565569 & underdamp \\
\hline & 142,84 & 1107,3 & 0.862026 & underdamp \\
\hline & 228,81 & 1773,7 & 1.380775 & overdamp \\
\hline \multirow{3}{*}{$\begin{array}{c}\text { Repsol } \\
10 \mathrm{wt}\end{array}$} & 102,03 & 768,48 & 0.600373 & underdamp \\
\hline & 155,51 & 1171,3 & 0.915061 & underdamp \\
\hline & 249,11 & 1876,2 & 1.465921 & overdamp \\
\hline
\end{tabular}

Dari data-data di atas dan dengan memperhatikan percepatan RMS penumpang, maka diperoleh variasi 
parameter suspensi yang menghasilkan redaman yang optimal, yaitu variasi ke-14, dimana digunakan jenis oli Repsol 10wt, dengan diameter orifice kompresi dan ekspansi masing-masing $\mathrm{Do}_{\mathrm{com}}=0,00135 \mathrm{~m}$, dan $\mathrm{Do}_{\text {exp }}=0,0009 \mathrm{~m}$. Variasi ini terpilih karena menghasilkan gaya redam yang besar yaitu $1171,3 \mathrm{~N}$, kemudian memiliki rasio redaman di bawah redaman kritis, dan menghasilkan respon percepatan pada penumpang lebih nyaman dibanding dengan suspensi asli.

3.2 Respon Dinamis Sistem Setengah Kendaraan Motor pada Penggunaan Sistem Suspensi Asli dan Modifikasi

Input Bump yang Dimodifikasi

- Severity parameter $=1$

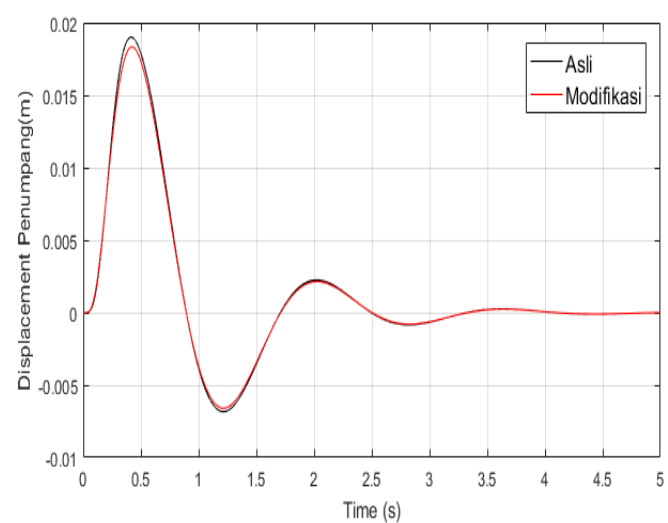

(a)

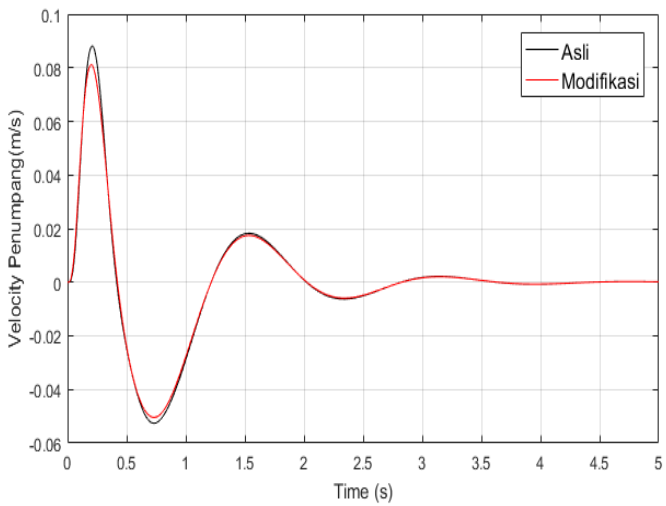

(b)

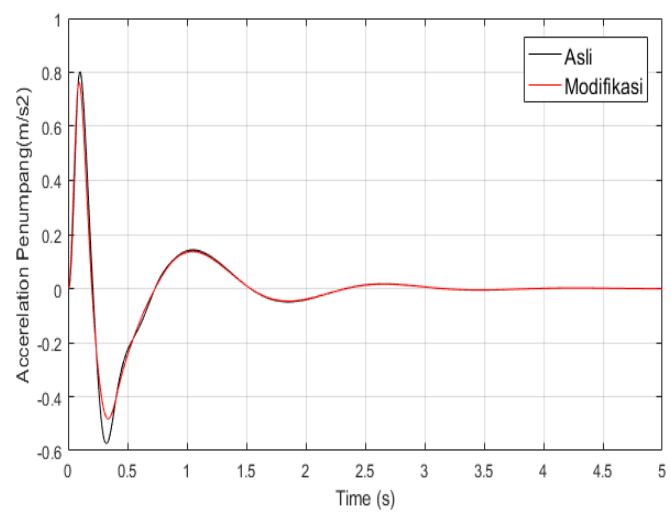

(c)

Gambar 4. Grafik respon (a) perpindahan, (b) kecepatan, (c) percepatan pada penumpang sepeda motor terhadap waktu dengan input bump modified ( $\gamma=$ 1)

- $\quad$ Severity parameter $=20$

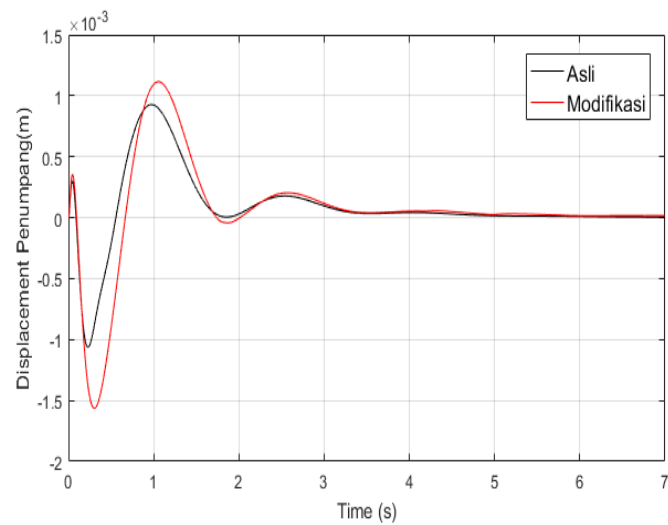

(a)

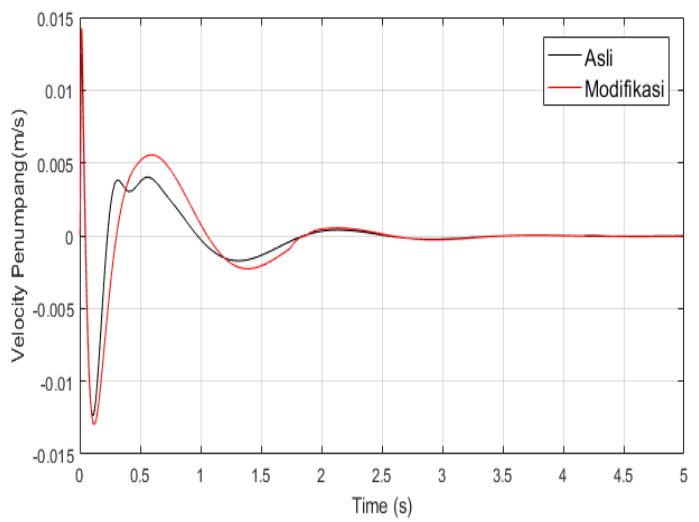

(b)

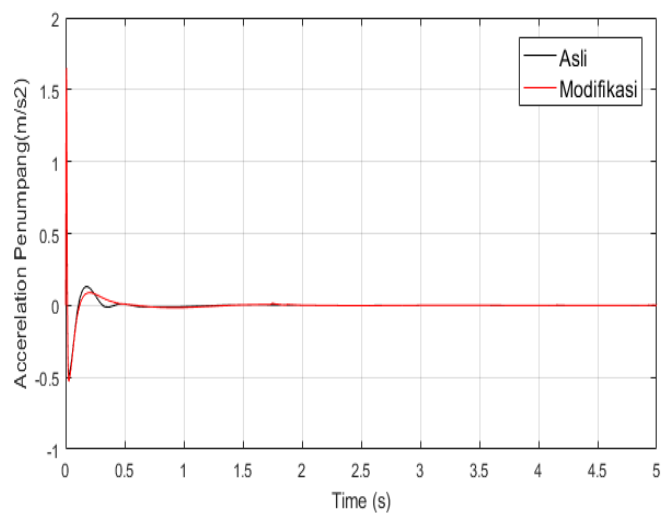

(c)

Gambar 5. Grafik respon (a) perpindahan, (b) kecepatan, (c) percepatan pada penumpang terhadap waktu dengan input bump modified $(\gamma=20)$

Dari gambar 4 dan 5 di atas, untuk low impact $(\gamma=1)$, didapatkan respon transient mencapai steady state sebelum 4 detik. Sementara untuk more severe impact $(\gamma=20)$, respon transient yang didapat berbeda-beda, respon perpindahan mencapai kondisi steady state sebelum 5 detik, respon kecepatan mencapai steady state sebelum 4 detik, dan respon percepatan mencapai steady state sebelum 3 detik.

Ketika low impact, nilai maksimum perpindahan sangat kecil, yaitu sebesar $0,0190 \mathrm{~m}$ saat menggunakan sistem suspensi asli dan 0,0183 m sistem suspensi modifikasi. Kemudian pada gambar 4(b), nilai maksimum kecepatan sebesar $0,0881 \mathrm{~m} / \mathrm{s}$ saat menggunakan sistem suspensi asli dan $0,0811 \mathrm{~m} / \mathrm{s}$ sistem suspensi modifikasi. Pada gambar 4(c) nilai maksimum percepatan sebesar $0,8023 \mathrm{~m} / \mathrm{s}^{2}$ saat menggunakan sistem suspensi asli dan $0,763 \mathrm{~m} / \mathrm{s}^{2}$ saat menggunakan sistem suspensi modifikasi.

Sementara itu untuk more severe impact pada gambar 5(a), nilai maksimum perpindahan sangat kecil, yaitu sebesar 
0,0009 $\mathrm{m}$ saat menggunakan sistem suspensi asli dan 0,0011 $\mathrm{m}$ sistem suspensi modifikasi. Pada gambar 5(b) nilai maksimum kecepatan sebesar $0,0125 \mathrm{~m} / \mathrm{s}$ saat menggunakan sistem suspensi asli dan $0,0143 \mathrm{~m} / \mathrm{s}$ sistem suspensi modifikasi. Pada gambar 5(c) nilai maksimum percepatan sebesar $1,4491 \mathrm{~m} / \mathrm{s}^{2}$ saat menggunakan sistem suspensi asli dan $1,6495 \mathrm{~m} / \mathrm{s}^{2}$ saat menggunakan sistem suspensi modifikasi.

Dari kedua kondisi di atas, maka diperoleh bahwa sistem suspensi modifikasi lebih cocok digunakan untuk low impact $(\gamma=1)$, karena menghasilkan respon yang lebih kecil dibanding suspensi asli.

\section{$>$ Input Sinusoidal}

- Kecepatan $=20 \mathrm{~km} / \mathrm{h}$

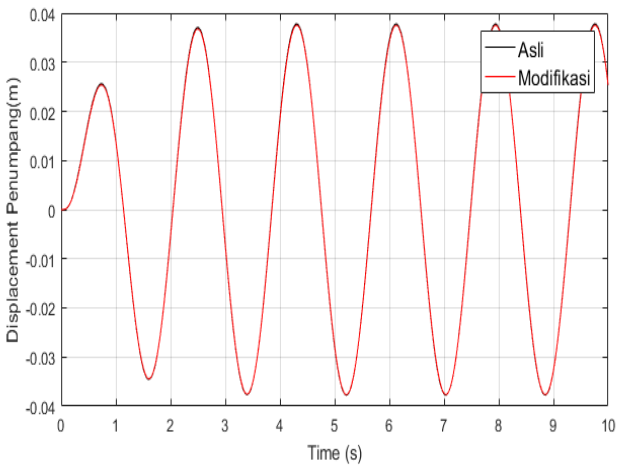

(a)

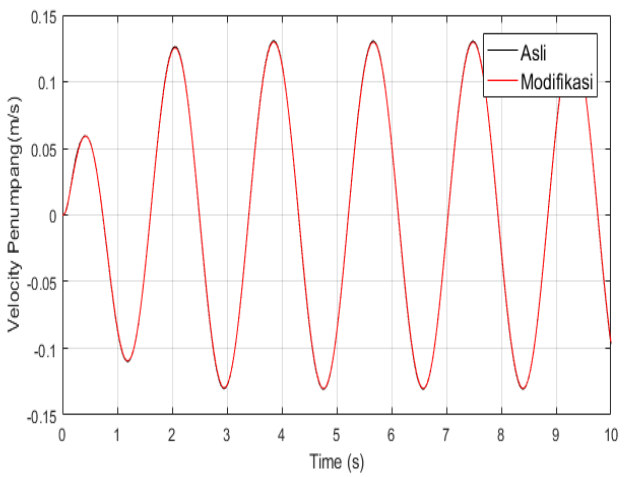

(b)

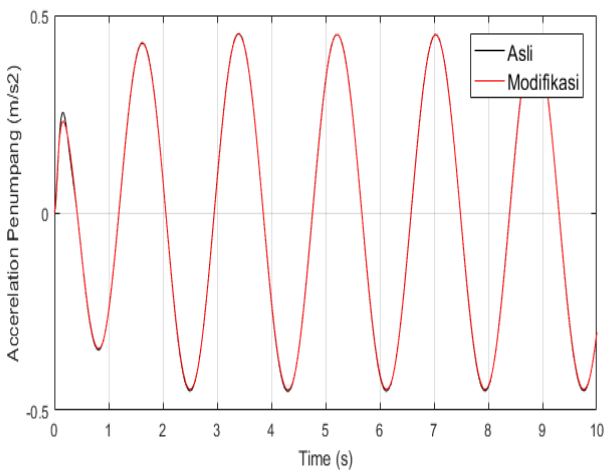

(c)

Gambar 6. Grafik respon (a) perpindahan, (b) kecepatan, (c) percepatan pada penumpang terhadap waktu pada $\mathrm{v}=20 \mathrm{~km} / \mathrm{jam}$

- Kecepatan $=60 \mathrm{~km} / \mathrm{h}$

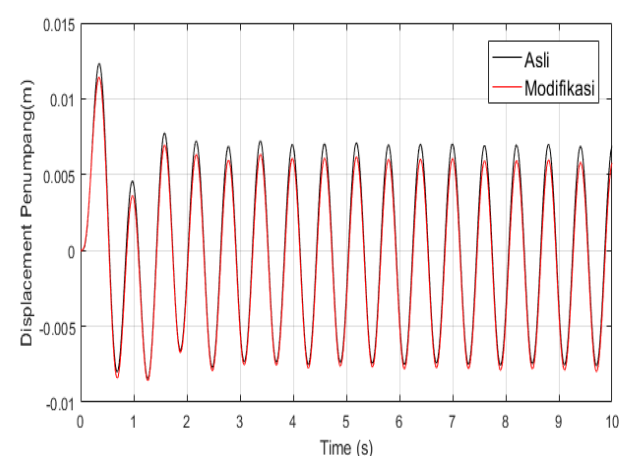

(a)

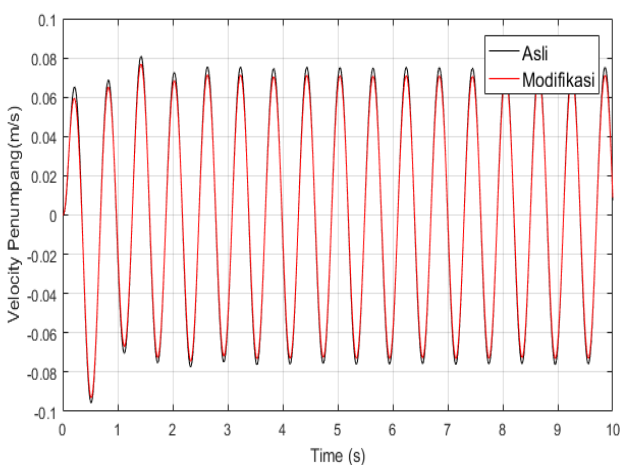

(b)

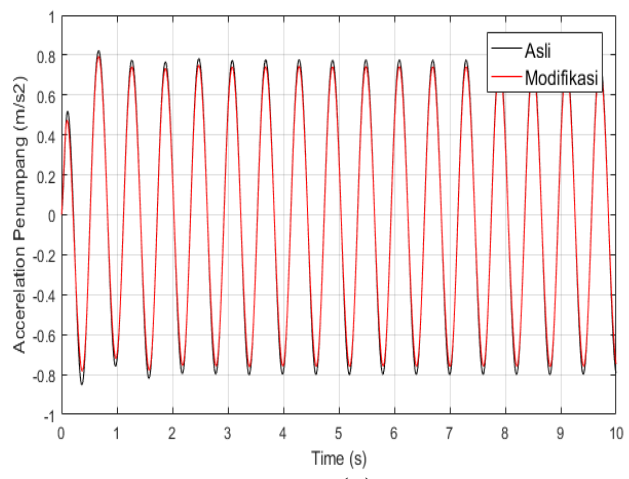

(c)

Gambar 7. Grafik respon (a) perpindahan, (b) kecepatan, (c) percepatan pada penumpang terhadap waktu pada $\mathrm{v}=60 \mathrm{~km} / \mathrm{jam}$

Dari simulasi menggunakan input sinusoidal didapatkan hasil seperti pada gambar 6 untuk kecepatan kendaraan $20 \mathrm{~km} / \mathrm{jam}$ dan gambar 7 untuk kecepatan $60 \mathrm{~km} / \mathrm{jam}$. Pada kecepatan $20 \mathrm{~km} / \mathrm{jam}$, respon mencapai kondisi steady state sebelum 3 detik. Sementara pada kecepatan $60 \mathrm{~km} / \mathrm{jam}$, mencapai steady state sebelum 2 detik.

Pada gambar 6(a), nilai maksimum perpindahan sebesar $0,0378 \mathrm{~m}$ saat menggunakan sistem suspensi asli, dan 0,0375 $m$ dengan sistem suspensi modifikasi. Pada gambar 6(b), nilai maksimum kecepatan sebesar $0,1307 \mathrm{~m} / \mathrm{s}$ saat menggunakan system sistem suspensi asli dan $0,1299 \mathrm{~m} / \mathrm{s}$ saat menggunakan sistem suspensi modifikasi. Pada gambar 6(c), nilai maksimum percepatan sebesar $0,4536 \mathrm{~m} / \mathrm{s}^{2}$ saat menggunakan sistem suspeni asli, dan $0,4525 \mathrm{~m} / \mathrm{s}^{2}$ saat menggunakan sistem suspensi modifikasi.

Sementara itu untuk kecepatan $60 \mathrm{~km} / \mathrm{jam}$ pada gambar 7(a), nilai maksimum perpindahan sangat kecil, yaitu sebesar $0,0123 \mathrm{~m}$ saat menggunakan sistem suspensi asli dan 0,0114 saat menggunakan sistem suspensi modifikasi. Pada gambar 7(b), nilai maksimum kecepatan sebesar $0,0808 \mathrm{~m} / \mathrm{s}$ saat menggunakan sistem suspensi asli dan 0,0767 saat menggunakan sistem suspensi modifikasi. Pada gambar 7(c), 
nilai maksimum percepatan sebesar $0,822 \mathrm{~m} / \mathrm{s}^{2}$ saat menggunakan sistem suspeni asli, dan $0,7935 \mathrm{~m} / \mathrm{s}^{2}$ saat menggunakan sistem suspensi modifikasi.

Apabila dibandingkan, maka terlihat dari trendline dan nilai respon perpindahan, kecepatan, dan percepatannya bahwa ketiga grafik cenderung berhimpit, hal ini dikarenakan gaya redam yang dihasilkan tidak terlalu besar dibandingkan dengan gaya pegas suspensinya, sehingga pengaruhnya terbilang kecil.

Sementara itu, untuk menganalisa kenyamanan kendaraan digunakanlah standar ISO 2631 dengan meninjau percepatan RMS penumpang. Nilai RMS untuk percepatan getaran penumpang saat kecepatan kendaraan $80 \mathrm{~km} / \mathrm{h}$ pada penggunaan sistem suspensi modifikasi adalah sebesar 0,6 $\mathrm{m} / \mathrm{s}^{2}$ dan $0,672 \mathrm{~m} / \mathrm{s}^{2}$ saat penggunaan sistem suspensi asli. Dari penggunaan sistem suspensi asli dan modifikasi, hasil dari nilai RMS dengan penggunaan sistem suspensi modifikasi memiliki nilai RMS yang sedikit lebih rendah jika dibandingkan dengan penggunaan sistem suspensi asli. Berdasarkan standar ISO 2631 diperoleh bahwa kriteria kenyamanan kendaraan dengan penggunaan suspensi asli maupun modifikasi adalah sama. Namun apabila dilihat dari nilai percepatan RMS modifikasi yang sedikit lebih kecil dibanding suspensi asli, maka dapat disimpulkan bahwa penggunaan suspensi modifikasi memberikan kenyamanan yang relatif lebih baik, terutama pada kecepatan tinggi.

\section{KESIMPULAN}

Berdasarkan hasil simulasi dan analisis pada sistem suspensi asli maupun modifikasi monotube hydraulic shock absorber, serta sistem setengah kendaraan sepeda motor dengan penggunaan monotube hydraulic shock absorber, maka dapat disimpulkan bahwa:

1. Sistem suspensi modifikasi monotube hydraulic shock absorber yang menghasilkan gaya redam optimal memiliki nilai parameter viskositas kinematis oli 46 $\mathrm{mm}^{2} / \mathrm{s}$, massa jenis oli $845 \mathrm{~kg} / \mathrm{m}^{3}$, diameter orifice kompresi $0,00135 \mathrm{~m}$, dan diameter orifice ekspansi $0,0009 \mathrm{~m}$;

2. Nilai gaya redam optimal yang dihasilkan sistem suspensi modifikasi adalah sebesar 1171,3 N saat ekspansi, lebih tinggi hingga 546,44 N dibandingkan dengan gaya redam ekspansi sistem supensi asli yang bernilai $624,86 \mathrm{~N}$ pada frekuensi $2 \mathrm{~Hz}$. Untuk gaya redam kompresi sebesar $142,84 \mathrm{~N}$, lebih tinggi $66,6 \mathrm{~N}$ dibanding suspensi asli yang gaya redam kompresinya sebesar $76,24 \mathrm{~N}$ pada freuensi 2 $\mathrm{Hz}$;

3. Untuk input bump, pada sistem setengah kendaraan motor dengan penggunaan sistem suspensi modifikasi maupun asli, respon kendaraan dan penumpang mencapai steady state kurang dari 2 detik dan 5 detik. Saat low impact $(\gamma=1)$, penggunaan suspensi modifikasi menghasilkan respon perpindahan, kecepatan, dan percepatan yang lebih kecil dibanding dengan penggunaan suspensi asli. Sedangkan untuk less severe impact $(\gamma=5)$ dan more severe impact $(\gamma=20)$, penggunaan suspensi modifikasi meghasilkan respon yang lebih besar dibanding penggunaan suspensi asli;

4. Untuk input sinusoidal, pada sistem setengah kendaraan motor dengan penggunaan sistem suspensi modifikasi maupun asli, respon kendaraan dan penumpang mencapai steady state kurang dari 2 detik dan 3 detik. Pada semua kecepatan kendaraan $(\mathrm{v}=20 \mathrm{~km} / \mathrm{jam} ; \mathrm{v}=40 \mathrm{~km} / \mathrm{jam} ; \mathrm{v}=$ $60 \mathrm{~km} / \mathrm{jam})$, penggunaan suspensi modifikasi menghasilkan respon perpindahan, kecepatan, dan percepatan yang lebih kecil dibanding penggunaan suspensi asli;

5. Berdasarkan standar ISO 2631, disimpulkan bahwa penggunaan sistem suspensi modifikasi menghasilkan kenyamanan yang lebih baik dibandingkan dengan penggunaan sistem suspensi asli. Hal ini dikarenakan nilai RMS percepatan getaran penumpang yang dihasilkan suspensi modifikasi lebih kecil dibanding suspensi asli, terutama saat $100 \mathrm{~km} / \mathrm{jam}$ yaitu sebesar $0,726 \mathrm{~m} / \mathrm{s}^{2}$ dan $0,639 \mathrm{~m} / \mathrm{s}^{2}$.

\section{UCAPAN TERIMA KASIH}

Penulis mengucapakan terima kasih kepada Bapak Dr. Harus Laksana Guntur ST, M.Eng dan Dr. Wiwiek Hendrowati, ST., MT. yang telah membantu penulis dalam melakukan penelitian ini.

\section{DAFTAR PUSTAKA}

[1] Rao, Singiresu S. 2011. Mechanical Vibrations Fifth Edition. Miami Pearson Education, Inc.

[2] Sutantra, Nyoman I. 2001. Teknologi Otomotif Teori dan Aplikasinya. Surabaya: Penerbit Guna Widya.

[3] ISO: Guide for The Evaluation of Human Exposure to Whole-Body Vibration. 1997. International Standart 2631. International Organization for Standardization.

[4] Fox dan McDonald's. 2011. Introduction to Fluid Mechanics Eighth Edition. Amerika: John Wiley \& Sons, Inc.

[5] Hestingrum, Yunita dan Laksana Guntur, Harus. 2015. Pemodelan dan Analisis Pengaruh Perubahan Parameter Sistem Suspensi OleoPneumatic terhadap Gaya Redam dan Gaya Pegas serta Respon Dinamis Penumpang Pesawat Boeing 747-400 Proses Landing dan Takeoff. Surabaya: Institut Teknologi Sepuluh Nopember Surabaya.

[6] Rahmawati, Istina dan Laksana Guntur, Harus. 2016. Pemodelan dan Analisis Pengaruh Perubahan Parameter Sistem Suspensi Hydro Pneumatic Terhadap Gaya Redam dan Gaya Pegas serta Respon Dinamis Mobil. Surabaya : Institut Teknologi Sepuluh Nopember Surabaya

[7] Olviani, Chika dan Laksana Guntur, Harus. 2014. Analisa Kenyamanan Kendaraan Roda Dua dengan Pemodelan Pengendara sebagai Sistem Multi D.O.F. Surabaya: Institut Teknologi Sepuluh Nopember Surabaya.

[8] Nugraha, Beni Setya. 2005. "Modul Chasis Sepeda Motor". Yogyakarta: Universitas Negeri Yogyakarta.

[9] Mulyo, Citro. 2013. "Modul Melakukan Perbaikan Sistem Suspensi", Pemalang: Sekolah Menengah Kejuruan Nusa Mandiri Pemalang.

[10] Peterverdone.2012."Suspension Oil Tuning Based On ISO Viscosity Grade".

<http://www.peterverdone.com/wiki/index.php?title=Suspension_Fl uid>.

[11] Greg. 2015. Calculating Motorcycle Center Of Mass. New Mexico: University of New Mexico.

[12] Wardani, Aulia. 2015. Pemodelan Dan Analisis Pengaruh Variasi Luasan Orifice Terhadap Gaya Redam, Daya Listrik Bangkitan, Dan Respon Dinamis Pada Hydraulic Motor Regenerative Shock Absorber (HMRSA). New Mexico: University of New Mexico.

[13] Kusuma, Budi Perdana. 2015. Studi Empirik Pengaruh Perubahan Viskositas Fluida Terhadap Respon Dinamis Dari Hydraulic Motor Regenerative Shock Absorber (HMRSA) New Mexico: University of New Mexico. 